$\begin{array}{ll} & \text { Etnográfica } \\ \text { etnográfica } & \text { Revista do Centro em Rede de Investigação em }\end{array}$

Antropologia

vol. 17 (1) | 2013

Vol. $17(1)$

\title{
Prémio Lévi-Strauss (ABA)
}

\section{Miguel Vale de Almeida}

\section{OpenEdition \\ Journals}

\section{Édition électronique}

URL : https://journals.openedition.org/etnografica/2608

DOI : 10.4000/etnografica.2608

ISSN : 2182-2891

\section{Éditeur}

Centro em Rede de Investigação em Antropologia

\section{Édition imprimée}

Date de publication : 1 février 2013

ISSN : 0873-6561

\section{Référence électronique}

Miguel Vale de Almeida, « Prémio Lévi-Strauss (ABA) », Etnográfica [En ligne], vol. 17 (1) | 2013, mis en ligne le 13 mars 2013, consulté le 11 février 2022. URL : http://journals.openedition.org/etnografica/ 2608 ; DOI : https://doi.org/10.4000/etnografica.2608

Ce document a été généré automatiquement le 11 février 2022.

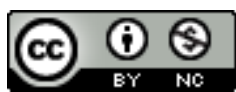

Etnográfica is licensed under a Creative Commons Attribution-NonCommercial 4.0 International License. 


\title{
Prémio Lévi-Strauss (ABA)
}

\author{
Miguel Vale de Almeida
}

A Associação Brasileira de Antropologia, através da sua Comissão de Educação, Ciência e Tecnologia, atribui, por ocasião das Reuniões Brasileiras de Antropologia, o Prémio Lévi-Strauss, visando dar visibilidade e estímulo à produção científica de jovens licenciandos/as brasileiros/as. É com muito prazer que partir de 2012 a Etnográfica se junta à $A B A$ oferecendo, como parte do prémio, a publicação do trabalho premiado na modalidade B (artigo).

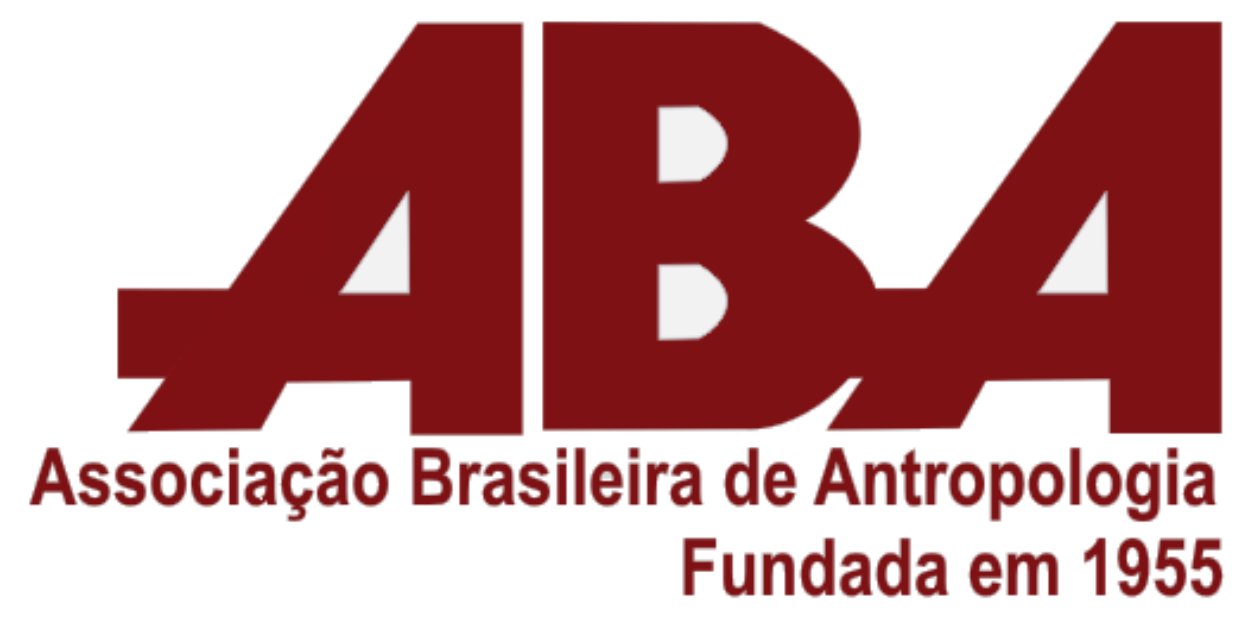

